\title{
Pengaruh Produk Domestik Regional Bruto, Inflasi, Upah Minimum, dan Jumlah Penduduk Terhadap Pengangguran di Indonesia Periode 2011 - 2017
}

\author{
Valentine Brahma Putri Sembiring ${ }^{*}$, Gatot Sasongko² \\ 1,2 Fakultas Ekonomi dan Bisnis, Universitas Kristen Satya Wacana Salatiga, Jawa Tengah, Indonesia
}

\author{
A R T I C L E I N F O \\ Article history: \\ Received 19 August 2019 \\ Received in revised form \\ 16 September 2019 \\ Accepted 15 October 2019 \\ Available online 30 \\ November 2019

\begin{tabular}{l}
\hline Kata Kunci: \\
Inflasi, Jumlah Penduduk, \\
PDRB, Pengangguran, Upah \\
Minimum \\
Keywords: \\
Inflation, GDP, Inflation, \\
Minimum wages, Population
\end{tabular} \\ Kata Kunci: \\ PDRB, Pengangguran, Upah \\ Inflation, GDP, Inflation, \\ Minimum wages, Population
}

\begin{abstract}
A B S T R A K
Penelitian ini merupakan penelitian kuantitatif dengan tujuan untuk mengetahui pengaruh PDRB, inflasi, upah minimum, dan jumlah penduduk terhadap pengangguran. Data yang digunakan berupa data panel 33 Provinsi selama 7 (tujuh) tahun terhitung dari 2011 - 2017. Sumber data berasal dari website resmi Badan Pusat Statistik dan Bank Indonesia. Uji hipotesis dianalisis menggunakan program eviews 9.0. Hasil penelitian membuktikan bahwa (1) Produk Domestik Regional Bruto berpengaruh negatif signifikan terhadap pengangguran, (2) Inflasi berpengaruh negatif signifikan terhadap pengangguran, (3) Upah Minimum berpengaruh negatif signifikan terhadap pengangguran, sementara (4) Jumlah Penduduk tidak berpengaruh terhadap pengangguran. Berdasarkan hasil kajian kebijakan yang dapat diambil pemerintah untuk menekan angka pengangguran antara lain dengan melakukan penyesuaian upah minimum dan melakukan kajian lebih dalam mengenai faktor yang dapat medorong naiknya PDRB.
\end{abstract}

\section{A B S T R A C T}

This research is a quantitative study with the aims to determine the effect of GDP, inflation, minimum wages, and population on unemployment. Using panel data of 33 Provinces in Indonesia in the 2011 - 2017 period. The data source comes from the official website of Badan Pusat Statistik and Bank Indonesia. Hypothesis was analyzed by using eviews 9.0 program. The result show that (1) GDP has a significant negative effect on unemployment, (2) Inflation has a significant negative effect on unemployment, (3) Minimum wages have a significant negative effect on unemployment, (4) The population does not affect unemployment. Based on the result, the suggestion for policies to reduce unemployment is to adjust the minimum wage and examine the factors that can increase GDP.

\footnotetext{
* Corresponding author.

E-mail addresses: gatot.sasongko@staff.uksw.edu (Gatot Sasongko)
} 


\section{Pendahuluan}

Dewasa ini pembangunan ekonomi merupakan salah satu topik hangat yang menjadi sorotan pemerintah. Pembangunan ekonomi merupakan proses menciptakan tambahan input untuk mendorong roda perekonomian negara sehingga terjadi peningkatan output secara terus menerus. Output yang dihasilkan oleh suatu negara dapat mengukur tingkat kemakmuran dan keberhasilan pembangunan ekonomi pada suatu daerah, sehingga upaya pembangunan ekonomi dikatakan berhasil apabila terjadi peningkatan output secara terus menerus dalam jangka waktu yang panjang, peningkatan tersebut kemudian akan mendorong penyerapan tenaga kerja dan naiknya pendapatan per kapita. Dengan kata lain, keberhasilan pembangunan ekonomi suatu negara ditentukan pula oleh produktivitas masyarakatnya, hal ini dikarenakan tinggi rendahnya produktivitas masyarakat akan berbanding lurus dengan total output yang dihasilkan suatu negara. Namun sayangnya realitas yang terjadi di Indonesia masih banyak masyarakat yang tidak produktif karena adanya hambatan dalam kesempatan kerja. Jumlah pencari kerja yang lebih besar dibandingkan daya tampung dari lapangan pekerjaan kemudian menimbulkan gap yang menjadi akar dari pengangguran.

International Labour Organisation mendefinisikan pengangguran sebagai kondisi dimana individu yang masuk dalam usia keja dalam periode tertentu namun tidak bekerja, bersedia untuk bekerja, atau sedang mencari pekerjaan (Byrne dan Strobl, 2004). Seseorang dikatakan tidak menganggur apabila sudah bekerja setidaknya selama satu minggu dan mendapatkan upah dari pekerjaan tersebut, sedangkan apabila seseorang tidak bekerja karena tidak memiliki pekerjaan, tengah mencari pekerjaan, atau menunggu panggilan pekerjaan, maka ia dikatakan sebagai pengangguran. Dengan kata lain, pengangguran ialah individu yang tidak memiliki peran dalam proses produksi barang dan jasa dalam jangka waktu tertentu (Mankiw, 2018).

Secara teoritis, pengangguran terjadi karena ketidakseimbangan di pasar tenaga kerja, dimana penawaran tenaga kerja lebih tinggi dibandingkan permintaanya, hal ini kemudian menimbulkan misalokasi tenaga kerja sehingga terdapat tenaga kerja tidak memperoleh pekerjaan dan menganggur. Studi yang dilakukan oleh peneliti terdahulu menuemukan beberapa faktor yang mempengaruhi pengangguran, diantaranya PDRB, inflasi, upah minimum, dan jumah penduduk pada daerah tersebut.

Menurut data yang dikeluarkan oleh World Bank, Indonesia termasuk salah satu negara dengan tingkat pengangguran tertinggi di Asia Tenggara, hal tersebut digambarkan melalui grafik di bawah ini

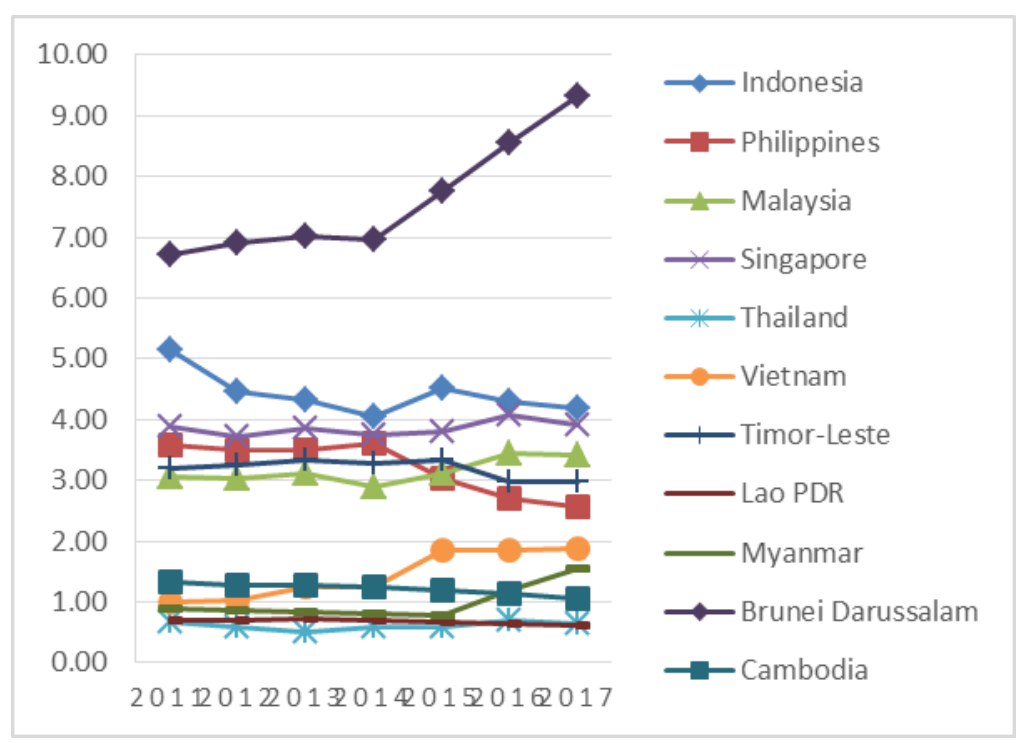

Sumber : Data World Bank, Unemployment, youth total (\% of total labor force ages 15-24) (modeled ILO estimate). (Diolah)

Gambar 1. Grafik Presentase Pengangguran di Asia Tenggara 2011 - 2017

Grafik 1 diatas menunjukkan kondisi ketenagakerjaan Asia Tenggara pada 7 (tujuh) tahun terakhir. Brunei Darusalam menduduki posisi pertama negara dengan jumlah pengangguran tertinggi di Asia Tenggara dengan rata-rata pengangguran sebesar 7,61 persen dan pertumbuhan sebesar 38,63 persen. Setelah itu, Indonesia menduduki posisi kedua dengan rata-rata pengangguran sebanyak 4,43 persen, namun pertumbuhannya menunjuukkan trend menurun sebesar -18,79 persen. Adapun Presentase 
pengangguran tertinggi di Indonesia terjadi pada tahun 2011 yaitu sebesar 5,15 persen, kemudian pada tiga tahun berikutnya mengalami trend menurun hingga menyentuh angka 4,05 di tahun 2014. Pada tahun 2015 terjadi kenaikan presentase pengangguran menjadi 4,51 persen, dilansir dari kompas.com Suhariyanto selaku analis statistik BPS mengatakan kenaikan presentase ini disebabkan oleh dua hal yaitu adanya pemutusan hubungan kerja dan menurunnya daya serap tenaga kerja di Indonesia Sebagian besar pemutusan kerja terjadi karena depresiasi rupiah, sehingga untuk menekan ongkos produksi perusahaan yang bergantung pada impor memilih untuk mengrangi jumlah tenaga kerjanya. Selain itu, turunnya daya serap tenaga kerja pada tahun 2015 disebabkan oleh kenaikan jumlah angkatan kerja sebesar 510 ribu jiwa. Kemudian, dua tahun berikutnya angka presentase pengangguran berangsur-angsur turun menjadi 4,30 persen di tahun 2016, dan 4,18 persen di tahun 2017.

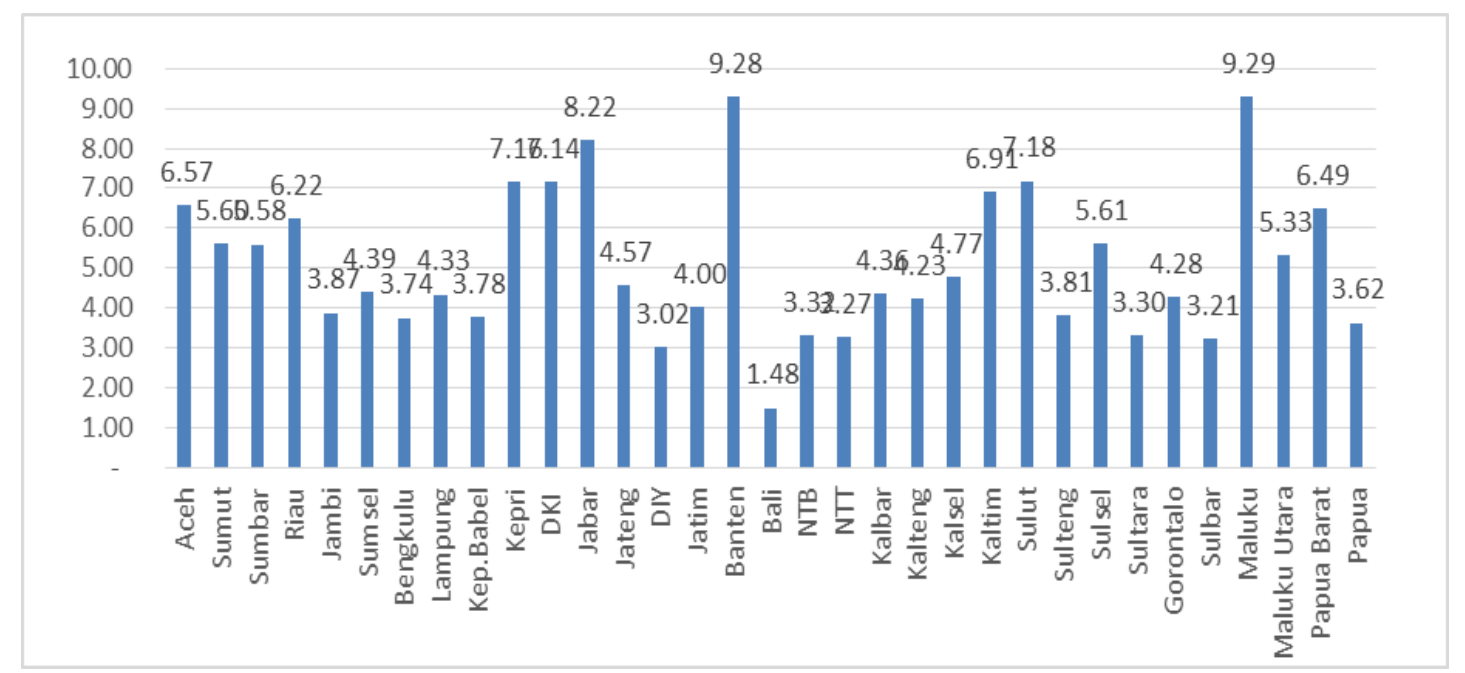

Sumber : BPS, Tingkat Pengangguran Terbuka (TPT) Menurut Provinsi, 1986-2018. (Diolah)

Gambar 2 Grafik Tingkat Pengangguran Terbuka 33 Provinsi di Indonesia Tahun 2017

Sama halnya dengan kondisi pengangguran pada skala Asia Tenggara yang menunjukkan tidak adanya negara yang luput dari masalah pengangguran, 33 Provinsi di Indonesiapun demikian. Grafik di atas menunjukkan bahwa Maluku merupakan provinsi dengan presentase pengangguran tertinggi di Indonesia, yaitu 9,29 persen. Data pendukung lain yang diperoleh dari BPS menginformasikan bahwa dari 707.796 jiwa angkatan kerja di Maluku, hanya 642.061 jiwa yang bekerja, sehingga terdapat 65,735 jiwa yang menganggur. Kemudian, Banten juga merupakan salah satu provinsi dengan tingkat TPT tertinggi di Indonesia dengan presentasi sebesar 9,28 persen, dimana 519.563 jiwa dari 5.596 .963 angkatan kerjanya menganggur. Selanjutnya, Jawa Barat menduduki posisi ketiga provinsi dengan TPT tertinggi di Indonesia, dengan presentase TPT sebanyak 8,22 persen. Apabila dilihat dari segi nominal, pengangguran Jawa Barat adalah yang terbesar, yaitu 1.839.428 jiwa, namun hal ini sebanding dengan jumlah angkatan kerjanya yang mencapai 22.391 .003 jiwa. Secara keseluruhan, besarnya rerata presentase pengangguran di 33 Provinsi di Indonesia adalah 5,09 persen, sehingga apabila ditinjau kembali masih terdapat 14 provinsi dengan tingkat TPT yang relatif tinggi dibandingkan 19 Provinsi lainnya. Kondsi ini menunjukkan bahwa masalah pengangguran masih menjadi problematika oleh banyak daerah di Indonesia.

Studi mengenai faktor-faktor yang mempengaruhi pengangguran telah dilakukan sebelumnya oleh beberapa peneliti terdahulu, faktor tersebut antara lain Produk Domestik Regional Bruto (PDRB). PDRB merupakan nilai tambah pada barang maupun jasa yang diperoleh dari kegiatan ekonomi pada periode tertentu, dalam usaha tersebut prodsuen memberikan tambahan input sehingga output yang dihasilkan memiliki nilai lebih. BPS Nasional mendefinisikan Produk Domestik Regional Bruto (PDRB) sebagai jumlah nilai tambah yang dihasilkan oleh seluruh unit usaha dalam suatu wilayah, atau merupakan jumlah seluruh nilai barang dan jasa akhir yang dihasilkan oleh seluruh unit ekonomi di suatu wilayah.

Tinggi rendahnya output merupakan salah satu parameter dalam mengukur kesejahteraan masyarakat suatu daerah, hal ini dikarenakan besarnya PDRB akan berbading lurus dengan produktifitas suatu daerah. Pengaruh output terhadap produksi dapat dijabarkan melalui fungsi produksi CobbDouglass sebagai berikut

$$
Y=A K^{\frac{1}{3}} L^{\frac{2}{3}}
$$


Variabel Y merupakan besaran output, A mewakili ketersediaan teknologi, K merupakan jumlah modal, dan L adalah tenaga kerja (Mankiw, 2018). Fungsi tersebut menjelaskan bahwa output akan berbanding lurus terhadap jumlah tenaga kerja, sehingga ketika ouput naik maka daya serap tenaga kerja juga akan meningkat, hal ini kemudian akan berdampak pada turunnya angka pengangguran. Adanya peran output dalam menekan angka pengangguran seperti yang dijelaskan dalam fungsi produksi didukung oleh teori yang dicetuskan oleh Arthur Melvin Okun (Okun's Law), ia meyakini bahwa pertumbuhan PDRB sebesar 3 persen akan menekan angka pengangguran sebesar 1 persen (Elshamy, 2013). Teori ini menjelaskan bahwa PDRB berpengaruh negatif terhadap pengangguran, sehingga ketika angka PDRB naik maka angka pengangguran akan turun, begitu pula sebaliknya. Hasil studi Elshamy (2013), Salman dan Shukur (2014), dan Chand, dkk (2017) membuktikan bahwa PDRB bepengaruh negatif terhadap pengangguran terbuka.

Berangkat dari hasil studi oleh peneliti terdahulu yang telah dipaparkan di atas hipotesis yang diajukan dalam penelitian ini sebagai berikut :

$\mathrm{Ha}_{1}$ : PDRB berpengaruh negatif terhadap pengangguran

Bank Indonesia mendefinisikan inflasi sebagai kecenderungan naiknya harga-harga secara umum dan terus menerus dalam periode waktu tertentu. Kurva Phillips yang dikemukakan oleh A.W Phillips meyakini adanya relevansi antara inflasi dan pengangguran. Teori ini menunjukkan bahwa hubungan inflasi dan pengangguran merupakan sebuah trade off, dimana ketika pemerintah menginginkan inflasi rendah, maka konsekuensi yang harus diterima adalah naiknya angka pengangguran, begitu pula sebaliknya. Naik turunnya permintaan agregat atas barang dan jasa di pasar akan memicu terjadinya perubahan harga atau Inflasi. Perubahan harga yang terjadi secara terus menerus kemudian memicu terjadinya perubahan di berbagai aspek ekonomi, salah satunya dalam bidang ketenagakerjaan. Secara lebih jelas hubungan inflasi dan pengangguran akan digambarkan oleh Kurva Phillips sebagai berikut

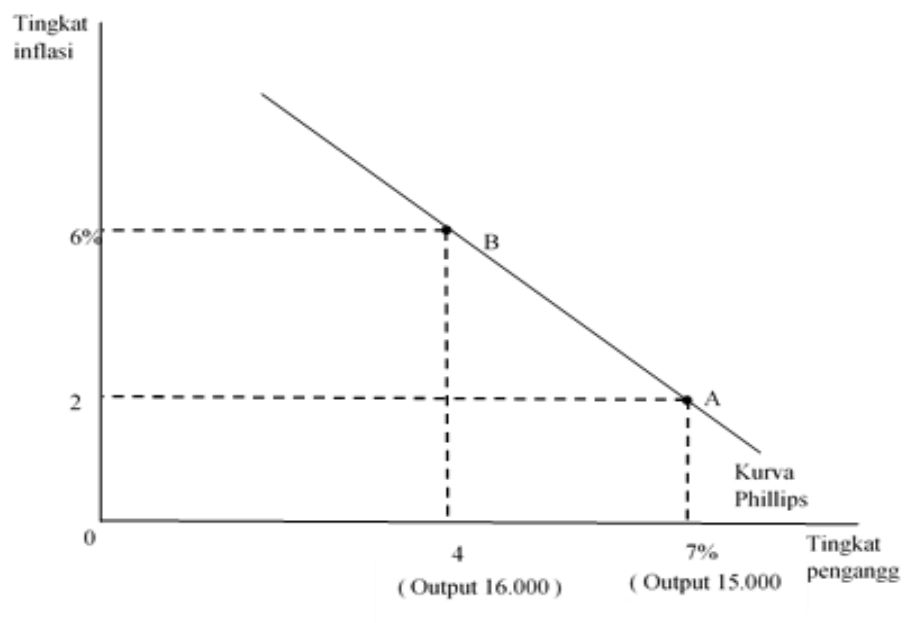

Gambar 3. Kurva Phillips (Mankiw, 2018)

Kurva Phillips di atas menunjukkan titik A merupakan kondisi permintaan agregat rendah, dengan output sebesar 15.000 maka tingkat inflasi berada pada 2 persen. Selanjutnya, ketika output naik menjadi 16.000 kondisi bergeser ke titik B, dimana pada kondisi terjadi kenaikan inflasi menjadi 6 pesen. Naiknya output sebesar 1.000 mendorong produsen untuk menambahkan input produksi salah satunya tenaga kerja, oleh karena itu terjadi penyerapan tenaga kerja sebesar 3 persen sehingga pengangguran berkurang menjadi 4 persen.

Dari hal yang telah dipaparkan diatas, hipotesa yang terbentuk sebagai berikut :

$\mathrm{Ha}_{2}$ : Inflasi berpengaruh negatif terhadap pengangguran

Kemudian, faktor lain yang diyakini mempengaruhi pengangguran adalah upah minimum. Upah didefinisikan oleh Badan Pusat Statistik Nasional dalam indikator tenaga kerja sebagai imbalan yang diberikan oleh perusahaan kepada karyawannya setelah karyawan tersebut memenuhi kewajibannya dalam kurun waktu tertentu, imbalan tersebut dapat berupa uang maupun barang. Sedangkan upah minimum merupakan hak pekerja/buruh yang diterima dan dinyatakan dalam bentuk uang sebagai imbalan dari pengusaha/ pemberi kerja kepada pekerja/buruh yang ditetapkan dan di bayarkan menurut suatu perjanjian kerja, kesepakatan, atau peraturan perundang-undangan termasuk tunjangan bagi pekerja/buruh dan keluarganya atas suatu pekerjaan dan/atau jasa yang telah atau akan dilakukan 
(Undang Undang Tenaga Kerja No.13 Tahun 2000, Bab I, pasal 1, Ayat 30). Adanya kebijakan penetapan upah minimum menjadi salah satu upaya pemerintah dalam mensejakterakan rakyatnya, dimana tujuan penetapan upah minimum sendiri untuk mencegah pekerja mendapatkan upah yang terlalu rendah, sehingga upah yang diterima seimbang dengan kinerja yang mereka lakukan dan besarannya dapat mencukupi kebutuhan untuk hidup yang layak.

Meskipun regulasi penetapan upah minimum akan menguntungkan pihak tenaga kerja, namun di sisi lain apabila upah minimum yang ditetapkan pemerintah di atas upah yang semula perusahaan berikan kepada karyawannya, maka regulasi tersebut dapat merugikan produsen sebagai pembuka lapangan kerja, karena kondisi ini mengharuskan perusahaan menambah ongkos produksi. Dengan kata lain adanya regulasi penetapan upah minimum akan mempengaruhi penawaran tenaga kerja begitu pula permintaannya di pasar tenaga kerja, seperti yang ditunjukkan oleh kurva di bawah ini.

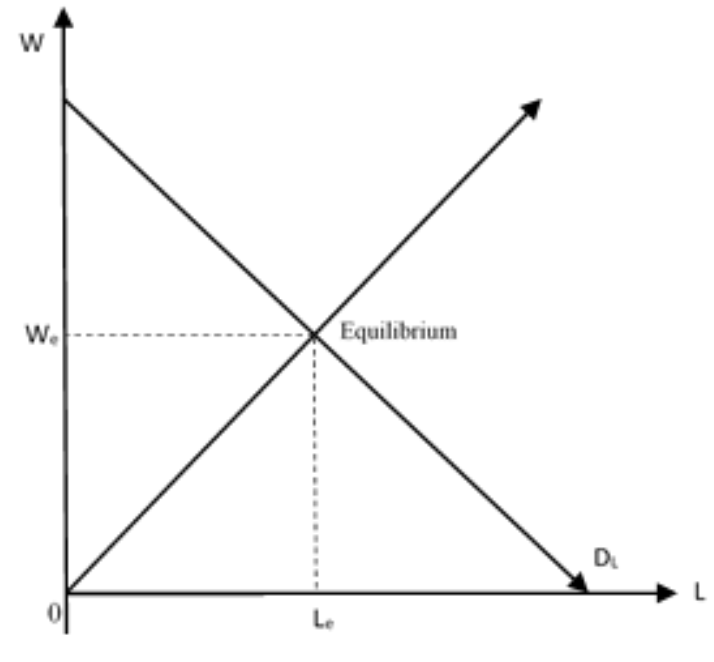

( A)

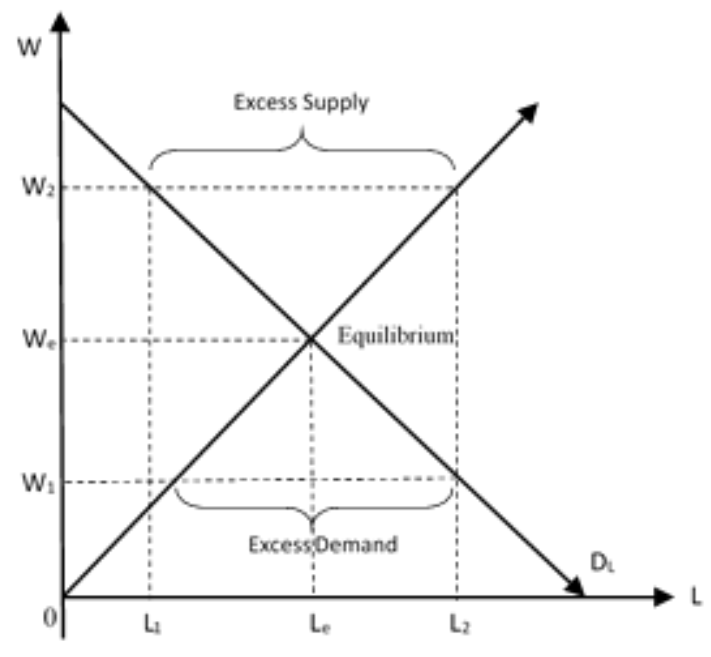

( B)

Gambar 4. Upah minimum di Pasar Kompetitif (Mankiw, 2018)

Kurva di atas menunjukkan perubahan kondisi ketenagakerjaan akibat penetapan upah minimum, permintaan tenaga kerja ditunjukkan oleh kurva menurun (downward sloping), sementara di sisi lain penawaran tenaga kerja ditunjukkan oleh kurva menaik (upward sloping). Kondisi A menggambarkan kondisi keseimbangan upah (W) dan pekerja (L), pada upah sebesar We tenaga kerja terserap secara maksimal, sehingga diasumsikan tidak terjadi pengangguran. Selanjutnnya, pada kondisi B pemerintah meningkatkan upah minimum, sehingga $W_{\mathrm{e}}$ akan bergeser ke $W_{2}$, hal ini kemudian mempengaruhi permintaan tenaga kerja, yang semula berada pada $\mathrm{L}_{e}$ selanjutnya bergeser ke $\mathrm{L}_{1}$, begitu pula pada penawaran tenaga kerja yang semula seimbang di $\mathrm{L}_{e}$ bergeser ke $\mathrm{L}_{2}$. Selisih $\mathrm{L}_{1}$ dan $\mathrm{L}_{2}$ menunjukan gap antara lapangan pekerjaan dan pencari pekerjaan di pasar tenaga kerja, sehingga selisih antara $L_{1}$ dan $L_{2}$ menjadi besaran angka pengangguran, hal ini menunjukkan bahwa penetapan upah minimum akan memicu terjadinya pengangguran.

Kurva di atas sejalan dengan hasil penelitian Uk Kim and Lim (2018) dan Caliendo, dkk (2018). Studi oleh Uk Kim and Lim (2018) mengatakan rata-rata kenaiakan upah sebesar 10 persen akan meningkatkan pengangguran sebesar 0,64 persen, penelitian serupa yang dilakukan oleh Caliendo, dkk (2018) menemukan bahwa upah minimum menyebabkan turunnya daya serap tenaga kerja, dimana terdapat penurunan angka tenaga kerja sebesar 0,025 persen tiap kenaikan satu point presentase upah minimum.

Dari pemaparan di atas kemudian dirumuskan hipotesa sebagai berikut

$\mathrm{Ha}_{3}$ : Upah minimum berpengaruh positif terhadap pengangguran

Selain ketiga faktor di atas, hasil kajian peneliti terdahulu menemukan pengaruh jumlah penduduk terhadap pengangguran. Hasil studi Gideon (2017) menunjukkan adanya peningkatan angka pengangguran sebesar 0,37 persen setiap populasi bertambah satu juta orang.

Badan Pusat Statistik mendefiniskan penduduk sebagai individu yang telah menetap di wilayah geografis Indonesia selama enam bulan atau lebih. Thomas Robert Malthus dalam teorinya mengatakan bahwa pertumbuhan manusia lebih cepat dibandingkan pertumbuhan sumber daya yang diperlukan mencukupi kebutuhan hidupnya, dimana manusia berkembang sesuai deret ukur $(2$ ke 4, 8, 16, 32, 64, dan 
seterusnya) sedangkan pertumbuhan sumber daya yang dibutuhkan untuk mencukupi kehidupan meningkat sesuai deret hitung ( 2 ke 4, 6, 8, 10, 12, dan setersunya). Karena adanya kesenjangan pada pertumbuhan kedua variabel tersebut, maka Malthus meyakini akan terdapat suatu masa dimana sumber daya tidak lagi mampu mencukupi kebutuhan manusia (Mulyadi, 2003).

Lapangan pekerjaan merupakan salah satu sumber daya yang dibutuhkan manusia sebagai sarana untuk mencukupi kebutuhan hidupnya, apabila berpatokan pada teori Malthus, pertumbuhan jumlah penduduk akan lebih cepat dibandingkan pertumbuhan lapangan kerja, sehingga akan terjadi kondisi dimana terjadi ketidakseimbangan jumlah pencari pekerjaan dan lapangan pekerjaan yang tersedia, gap tersebut kemudian menimbulkan adanya pengangguran.

Dari pemaparan diatas, hipotesa yang diajukan sebagai berikut

$\mathrm{Ha}_{4}$ : Jumlah penduduk berpengaruh terhadap pengangguran

Berdasarkan pemaparan teori dan hasil studi terdahulu yang telah dipaparkan di atas, penelitian ini dilakukan dengan tujuan menguji dan menganalis pengaruh Produk Domestik Regional Bruto, inflasi, upah minimum, dan jumlah penduduk terhadap pengangguran di 33 Provinsi di Indonesia, tahun 2011 2017.

\section{Metode}

Penelitian ini menggunakan metode analisis kuantitatif, dimana metode tersebut dipilih guna memperoleh gambaran jelas mengenai suatu fenomena berlandaskan intepretasi terhadap hasil olahan model dengan metode analisis panel data.

Data panel merupakan gabungan antara data silang (cross section) dan data runtut waktu (time series), dimana data ini meliputi suatu objek dalam beberapa periode (Winarno, 2007). Kelebihan dari data panel dibandingkan jenis data cross section maupun time series adalah dapat memberikan jumlah pengamatan yang lebih besar dan informasi lebih banyak sehingga menghasilkan estimasi ekonometri yang lebih efisien.

Jenis data yang digunakan dalam penelitian ini merupakan data sekunder, dimana data ini diperoleh dari mengakses website instansi yang menerbitkan data statistik diantaranya Badan Pusat Statistik baik nasional maupun provinsi. Pada penelitiaan ini digunakan data panel yang merupakan kolaborasi data time series selama enam tahun terhitung dari 2011 hingga 2017 dan data cross sectional dari 33 Provinsi di Indonesia.

Data yang digunakan merupakan data sekunder yang diperoleh dari Badan Pusat Statistik dan Bank Indonesia, kemudian diuji menggunakan program Eviews 9.0.

Selanjutnya model regresi yang digunakan pada penelitian ini adalah sebagai berikut (Winarno,2015)

$$
Y_{\text {it }}=\beta+\beta_{1} X 1_{\text {it }}+\beta_{2} X 2_{i t}+\beta_{3} X 3_{i t}+\beta_{4} X 4_{\text {it }}+e_{\text {it }}
$$

dimana,

$\begin{array}{ll}\mathrm{Y} & : \text { Variabel Terikat } \\ \mathrm{B} & : \text { Koefisien Regresi } \\ \mathrm{X} 1, \mathrm{X} 2, \mathrm{X} 3, \mathrm{X} 4 & : \text { Variabel-variabel bebas } \\ \mathrm{e} & : \text { Error Term } \\ \mathrm{t} & : \text { Waktu } \\ \mathrm{i} & : \text { Objek }\end{array}$

Pengujian pada data dilakukan dalam beberapa tahap sebagai berikut

Uji Stasioner Data Panel

Uji stasioner merupakan pengujian pertama yang harus dilakukan sebelum melakukan regresi data panel. Tujuan dari dilakukannya pengujian ini untuk membuktikan bahwa data yang digunakan bersifat stasioner, dimana varians antar data tidak terlalu besar, dengan kata lain variabel dikatakan stasionel apabila sebaran data berada pada nilai rata-rata dari variabel tersebut.

Pengujian ini akan dikaji menggunakan uji Levin, apabila data pada order nol (I[0]) data tidak stasioner maka akan dilakukan pengujian ulang pada order selanjutnya yaitu first difference dan apabila hasil yang diperoleh belum stasioner akan dilakukan pengujuian lagi di order selanjutnya yaitu second difference (Winarno, 2015)

Untuk menguji kestasioneran data digunakan uji Unit Root Test dengan hipotesis sebagai berikut : 
$\mathrm{H}_{0}: \quad$ Terdapat akar unit

$\mathrm{H}_{\mathrm{a}}$ : $\quad$ Tidak terdapat akar unit

Uji Regresi Data Panel

Berangkat dari teori dan penelitian terdahulu mengenai pengaruh PDRB Per-kapita, inflasi, dan upah minimum terhadap pengangguran, maka akan dilakukan pengujian terhadap data tahunan 33 Provinsi di Indonesia menggunakan uji regresi data panel, oleh sebab itu dilakukan uji spersifikasi model untuk mendapatkan model paling tapat dalam teknik penduga data panel. Untuk melakukan estimasi model dengan data panel, terdapat tiga pendekatan yang dapat digunakan dalam pengujian diantaranya fixed effect, common effect, dan random effect, dengan pemaparan sebagai berikut (Winarno, 2015) :

Model Fixed Effect:

$Y_{i t}=\alpha_{0 i}+\beta_{1} X_{i t}+\beta_{2} X_{i t 2}+\beta_{3} X_{i t 3}+\beta_{4} d_{i i}+\ldots+\beta_{37} d_{32 i}+e_{i t}$

Model Common Effect :

$Y_{i t}=\alpha_{0}+\beta X_{i t}+\beta_{2} X_{i t 2}+\beta_{3} X_{i t 3}+\beta_{4} X_{i t 4}+e_{i t}$

Model Random Effect :

$Y_{\mathrm{it}}=\alpha_{0 \mathrm{i}}+\beta X_{\mathrm{it}}+\beta_{2} X_{\mathrm{it} 2}+\beta_{\mathrm{g}} X_{\mathrm{ita}}+e_{\mathrm{t}}$

dimana,

$Y_{\text {it }}$ : Variabel pengangguran pada provinsi dan periode tertentu

$\mathrm{X}_{\mathrm{it}}$ : Variabel PDRB Per-Kapita pada provinsi dan periode tertentu

$\mathrm{X}_{\mathrm{it} 2}$ : Variabel inflasi pada provinsi dan periode tertentu

$\mathrm{X}_{\mathrm{it} 3}$ : Variabel upah minimum pada provinsi dan periode tertentu

$\mathrm{X}_{\mathrm{it} 4}$ : Variabel jumlah penduduk pada provinsi dan periode tertentu

Dalam memilih model yang paling tepat untuk mengolah data panel dilakukan dua pengujian. Pertama, dilakukan Uji Chow untuk memilih model terbaik antara Common Effect atau Fixed Effect.

Adapun hipotesis dari pengujian ini adalah

$\mathrm{H}_{0}$ : Model terpilih adalah common effect $(\alpha>10 \%)$

$\mathrm{H}_{\mathrm{a}}$ : Model terpilih adalah fixed effect $\quad(\alpha<10 \%)$

Uji Asumsi Klasik Data Panel

Uji Multikolinearitas

Pengujian ini bertujuan untuk membuktikan bahwa pada data yang diuji tidak terdapat hubungan linear antar variabel independent (Winarno, 2015). Variabel yang meiliki korelasi antar variabel independent menunjunjukkan variabel tersebut tidak ortogonal, hal ini ditunjukkan dengan nilai korelasi antar sesama variabel independent sama dengan nol. Multikolineraritas di dalam model regresi dapat dideteksi dengan ketentuan 1). Nilai R yang dihasilkan oleh suatu estimasi model regresi empiris sangat tinggi, tetapi secara individual variabel-variabel independen banyak yang tidak signifikan mempengaruhi variabel dependen. 2). Menganalisis matriks korelasi variabel-variabel independen. Jika antar variabel ada korelasi yang cukup tinggi (umumnya lebih dari 0,80), maka hal ini merupakan indikasi adanya multikolinieritas. Tidak adanya korelasi yang tinggi antar variabel independen tidak berarti bebas dari multikolinieritas.

Hipotesis dalam pengujian dirumuskan sebagai berikut :

$\mathrm{H}_{0}$ : Tidak terjadi multikolinearitas dalam model

$\mathrm{H}_{\mathrm{a}}$ : Terjadi multikolinearitas dalam model

Uji Heterokedastisitas

Pengujian ini dilakukan untuk membuktikan tidak ada variance dari residual satu pengamatan ke pengamatan lain yang tidak sama (Gujarati, 2006). Variabel dinyatakan lolos (homoskedastisitas) apabila viariance dari residual satu pengamatan ke pengamatan yang lain tetap, hal ini ditunjukkan dengan nilai $p$ value $>0,05$ pada model regresi. Namun apabila residual satu pengamatan ke pengamatan yang lain 
berbeda maka variabel terindikasi masalah herteroskedastisitas sehingga dibutuhkan pengujian lebih lanjut untuk mengobatinya. Uji heteroskedatisitas dapat dinyatakan dengan hipotesis :

H0 : Asumsi homokedastisitas terpenuhi

Ha : Asumsi homokedastisitas tidak terpenuhi

\section{Hasil dan pembahasan}

Uji Stasioneritas Data Panel

Pengujian pertama yang dilakukan dalam penelitian ini adalah uji stasioneritas, dimana dalam pengujian ini uji stasioneritas dilakukan dengan menggunakan metode Levin

Tabel 1. Hasil Uji Stasioner

\begin{tabular}{lll} 
Variabel & $\begin{array}{l}\text { Tingkat Stasionaritas } \\
\text { Level }(0) \\
\text { Prob. Uji Levin }\end{array}$ & Keterangan \\
\hline LTPT & 0.0000 & Stasioner \\
LPDRB & 0.0029 & Stasioner \\
Inflasi & 0.0000 & Stasioner \\
LUM & 0.0000 & Stasioner \\
LJP & 0.0000 & Stasioner \\
\hline
\end{tabular}

Hasil pengujian menunjukkan bahwa pada uji stasioneritas menggunakan metode Levin ke keempat variabel dinyatakan lolos uji pada tingkat level, hal ini dibuktikan oleh probabilitas pada variabel pengangguran yang diwakilkan oleh LTPT sebesar 0,0000 pada variabel LPDRB sebesar 0,0029, pada variabel Inflasi sebesar 0,0000, pada variabel upah minimum yang diwakilkan oleh LUM sebesar 0,0000, dan variabel jumlah penduduk yang diwakilkan oleh LJP sebesar 0,0000. Probabilitas dari ke-empat variabel ini lebih kecil dibandingkan taraf nyatanya $(\alpha=5 \%)$ sehingga hasil pengujian menunjukkan bahwa $\mathrm{H}_{0}$ ditolak dan $\mathrm{H}_{\mathrm{a}}$ diterima.

Dapat disimpulkan bahwa besaran angka pada data Pengangguran, PDRB Per-Kapita , Inflasi, Upah Minimum, dan Jumlah Penduduk adalah stasioner, yang mana hal ini menunjukkan bahwa varians angka pada data tersebut tidak jauh dengan besarnya angka rata-rata pada variabel tersebut. Lolosnya data pada uji stasioner menunjukkan karateristik data yang stabil sehingga data ini layak untuk melakukan pengujain selanjutnya.

\section{Uji Data Panel}

Setelah membuktikan bahwa data yang diuji stasioner, dilanjutkan dengan uji regresi data panel untuk membuktikan adanya pengaruh variabel PDRB Per-Kapita, Inflasi, dan Upah minimum terhadap pengangguran seperti yang telah di paparkan pada hipotesis. Namun sebelum melakukan uji regresi data panel, data harus terlebih dahulu diuji menggunakan Uji Chow untuk memilih model yang tepat dalam teknik penduga data panel.

Tabel 2. Hasil Uji Chow

\begin{tabular}{llll}
\hline Effects Test & Statistic & d.f. & Prob. \\
\hline Cross-section F & 32.621570 & $(32,194)$ & 0.0000 \\
Cross-section Chi-square & 428.113600 & 32 & 0.0000 \\
\hline
\end{tabular}

Pada Uji Chow diperoleh probabilitas Cross-section F dan Cross-sectiom Chi-square sebesar 0,0000 besaran angka ini kurang dari nilai taraf nyata $(\alpha=10 \%)$ sehingga $\mathrm{H}_{a}$ diterima dan $\mathrm{H}_{0}$ ditolak. Pengujian ini membuktikan bahwa fixed effect merupakan model terbaik dalam menganalisa data

\section{Uji Asumsi Klasik (Multikolinearitas)}

Setelah menemukan model terbaik, selanjutnya dilakukan uji multikolinearitas yang merupakan salah satu tahap pengujian pada uji asumsi klasik. Pengujian ini dilakukan untuk memastikan tidak tejadi korealasi yang kuat antara variabel bebas, adapun hasil dari pengujian ditunjukkan pada tabel 4 berikut 
Tabel 3. Hasil Uji Multikolinearitas Pertama

\begin{tabular}{lllll}
\hline & LPDRB & INFLASI & LUM & LJP \\
\hline LPDRB & 1.000000 & -0.027627 & 0.057604 & $0.877570^{*}$ \\
INFLASI & -0.027627 & 1.000000 & -0.177031 & -0.021409 \\
LUM & 0.057604 & -0.177031 & 1.000000 & -0.190241 \\
LJP & $0.877570^{*}$ & -0.021409 & -0.190241 & 1000000 \\
\hline
\end{tabular}

Ket : *: Tidak lolos uji

Hasil uji multikolinearitas pada variabel PDRB, inflasi, upah minimum, dan jumlah penduduk menunjukkan adanya korelasi antara PDRB dan jumlah penduduk, hal ini ditunjukkan oleh angka korelasi kedua variabel sebesar 0.877570 sehingga $\mathrm{H}_{0}$ ditolak dan $\mathrm{H}_{\mathrm{a}}$ diterima.

Untuk mengobati multikolinearitas yang terjadi pada data maka dilakukan pengujian ulang dengan mengganti angka PDRB dengan angka residualnya. Setelah dilakukan pengujian ulang, berikut hasil yang diperoleh

Tabel 4. Hasil Uji Multikolinearitas Kedua

\begin{tabular}{lllll} 
& LPDRB & INFLASI & LUM & LJP \\
\hline LPDRB & 1.000000 & -0.163590 & 0.277116 & -0.000991 \\
INFLASI & -0.163590 & 1.000000 & -0.233775 & -0.055594 \\
LUM & 0.277116 & -0.233775 & 1.000000 & -0.093540 \\
LJP & -0.000991 & -0.055594 & -0.093540 & 1.000000 \\
\hline
\end{tabular}

Hasil pengujian diatas menunjukkuan pada variabel PDRB, angka korealsi terhadap variabel Jumlah Penduduk adalah -0.000991, 0.277116 terhadap variabel Upah Minimum, dan -0.163590 terhadap variabel inflasi. Kemudian, hasil uji multikolineritas pada variabel inflasi menunjukkan PDRB memiliki korelasi sebesar -0.163590 terhadap inflasi, sedangkan upah minimum memiliki korelasi sebesar 0.233775 dan jumlah penduduk sebesar -0.055594. Selanjutnya, pada variabel upah minimum, PDRB memiliki korelasi sebesar 0.277116 , inflasi sebesar -0.233775 , dan jumlah penduduk sebesar -0.093540 . Pada variabel jumlah penduduk, ditemukan korelasi PDRB sebesar -0.000991, Inflasi sebesar -0.055594, dan upah minimum sebesar -0.093540. Hasil pengujian membuktikan pada ke empat variabel independent tidak terjadi multikolinearitas, karena angka korelasi antar variabel kurang dari 0,8.

Uji Asumsi Klasik (Heterokedastisitas)

Uji heterokedastisitas merupakan salah satu pengujian dari uji asumsi klasik. Pengujian ini dilakukan untuk mengamati apakah pada residual seluruh model regresi linear terdapat ketidak samaan varian, adapaun hasil pengujian yang didapatan adalah sebagai berikut

Tabel 5. Hasil Uji Heteroskedastisitas

\begin{tabular}{ll}
\hline Dependent Variable : RESABS & \\
Varaiabel & Prob. \\
\hline PDRBBARU & 0.6961 \\
Inflasi & 0.0788 \\
LUM & 0.9563 \\
LJP & 0.8703 \\
\hline
\end{tabular}

Dari hasil pengujian data ke-empat variabel terbukti homokedastisitas, hal ini ditunjukkan dari nilai signifikansi variabel PDRB sebesar 0.6961, sedangkan variabel inflasi 0.0788, variabel upah minimum sebesar 0.9563, dan variabel jumah penduduk sebesar 0.8703. Besaran angka dari hasil pengujian keempat variabel lebih besar dari nilai taraf nyata ( $\alpha=5 \%$ ), sehingga terbukti pada data yang diujikan terdapat ketidaksamaan variance dari residual satu pengamatan ke pengamatan yang lain.

Uji Regresi Data Panel

Berangkat dari hasil uji spesifikasi model yang menunjukkan fixed effect merupakan model terbaik untuk pengujian ini, maka selanjutnya dilakukan uji regresi data panel menggunkan model tesebut dengan hasil uji sebagai berikut 
Tabel 6. Hasil Uji Regresi data Panel

\begin{tabular}{llll}
\hline Variabel & Koefisien & T-Statistik & Prob. \\
\hline C & -2.423330 & -0.183632 & 0.8545 \\
PDRBBARU & -0.715768 & -2.792427 & 0.0058 \\
Inflasi & -0.008315 & -1.715328 & 0.0879 \\
LUM & -0.225280 & -1.749890 & 0.0817 \\
LJP & 0.477383 & 0.489380 & 0.6251 \\
\hline R-Squared & 0.859297 & & \\
Prob (F-Statistik) & 0.000000 & & \\
\hline
\end{tabular}

Pada hasil pengujian yang ditunjukkan oleh tabel 5 diketahui bahwa variabel PDRB berpengaruh negatif dan signifikan terhadap pengangguran, hal tersebut dibuktikan dari perolehan nilai koefisien sebesar -0.715768 dan besaran probabilitas yang lebih kecil dibandingkan nilai taraf nyata ( $\alpha=10 \%$ ). Kemudian, pada variabel inflasi, hasil pengujian membuktikan adanya pengaruh negatif terhadap pengangguran secara signifikan, dibuktikan dengam nilai (-) pada koefisien inflasi dan probabilitasnya lebih kecil dibandingkan nilai taraf nyata $(\alpha=10 \%)$. Selanjutnya variabel Upah Minimum menunjukkan hasil yang sama dengan dua variabel sebelumnya yaitu berpengaruh negatif dan signifikan terhadap pengangguran, dengan nilai koefisien sebesar -0.225280 dan probabilitas lebih rendah dibandingkan nilai taraf nyata $(\alpha=10 \%)$. Namun, pada variabel jumlah penduduk perolehan hasil tidak menemukan adanya pengaruh jumlah penduduk terhadap pengangguran, dimana probabilitas menunjukkan angka yang lebih besar dari nilai taraf nyata ( $\alpha=10 \%$ ). Adapun angka R-Squared pada hasil uji membuktikan bahwa secara bersama-sama, variabel PDRB, Inflasi, upah minimum, dan jumlah penduduk mempengaruhi pengangguran sebesar $85 \%$ sedangkan $15 \%$ nya dipengaruhi oleh faktor lain diluar variabel penelitian.

Pembahasan

Pada hasil uji pengaruh PDRB terhadap penganguran didapatkan koefisian sebesar -0.715768 dan signifikan pada 1 persen. Hasil uji ini mendukung hipotesa penelitian $\left(\mathrm{Ha}_{1}\right)$ yang meyakini adanya hubungan negatif antara PDRB dan pengangguran, dimana tiap kenaikan PDRB sebesar 1 persen akan menyebabkan turunnya angka pengangguran sebesar 0,72 persen.

Hasil ini selajan dengan fungsi produksi Cobb-Douglass diamana kenaikan ouput akan berbanding lurus dengan penyerapan teanga kerja, sehingga kondisi ini akan meminimalisir terjadinya pengangguran. Pengaruh negatif PDRB terhadap pengangguran ini juga sejalan dengan Hukum Okun yang mengatakan naiknya 3 persen PDRB akan menekan pengangguran sebesar 1 persen.

Apabila ditelusuri lebih dalam, pada tahun 2011 hingga 2017 terdapat peningkatan output pada beberapa sektor lapangan pekerjaan di Indonesia sehingga mendorong perusahaan menambah jumlah tenaga kerjanya. Adapun sektor yang paling berpengaruh menekan angka pengangguran dapat dicermati melalui tabel dibawah ini

Tabel 7. Pertumbuhan Lapangan Kerja di Indonesia Tahun 2011 - 20117

\begin{tabular}{|c|c|c|c|c|c|c|c|c|c|}
\hline \multicolumn{10}{|c|}{ Growth } \\
\hline No. & Lapangan Pekerjaan Utama & 2011 & 2012 & 2013 & 2014 & 2015 & 2016 & 2017 & $\begin{array}{l}\text { Rata- } \\
\text { Rata }\end{array}$ \\
\hline 1 & $\begin{array}{l}\text { Pertanian, } \\
\text { Kehutanan, } \\
\text { Perikanan }\end{array}$ & $-2,24$ & 0,45 & $-0,33$ & $-0,22$ & $-1,07$ & 0,02 & $-1,53$ & $-0,70$ \\
\hline 2 & Pertambangan dan Penggalian & 0,17 & 0,15 & $-0,16$ & 0,01 & $-0,10$ & 0,13 & $-0,07$ & $-0,02$ \\
\hline 3 & Industri & 0,67 & 0,95 & $-0,58$ & 0,26 & 0,00 & 0,24 & 1,21 & 0,39 \\
\hline 4 & Listrik, Gas, dan Air Minum & 0,00 & 0,01 & 0,00 & 0,03 & 0,00 & 0,06 & 0,03 & 0,02 \\
\hline 5 & Konstruksi & 0,62 & 0,52 & $-0,45$ & 0,81 & 0,81 & 0,19 & 0,13 & 0,32 \\
\hline 6 & $\begin{array}{l}\text { Perdagangan, Rumah Makan dan } \\
\text { Jasa Akomodasi }\end{array}$ & $-0,18$ & 1,08 & 0,52 & 0,63 & 0,75 & 0,85 & 1,23 & 0,70 \\
\hline 7 & $\begin{array}{l}\text { Transportasi, Pergudangan dan } \\
\text { Komunikasi }\end{array}$ & $-0,57$ & 0,04 & 0,04 & 0,01 & $-0,01$ & 0,42 & 0,12 & 0,01 \\
\hline 8 & $\begin{array}{l}\text { Lembaga Keuangan, Real Estate, } \\
\text { Usaha Persewaan, dan Jasa } \\
\text { Perusahaan }\end{array}$ & 0,78 & 0,11 & 0,18 & 0,12 & 0,21 & 0,22 & 0,18 & 0,26 \\
\hline
\end{tabular}




\begin{tabular}{|c|c|c|c|c|c|c|c|c|c|}
\hline 9 & $\begin{array}{l}\text { Jasa Kemasyarakatan, Sosial, dan } \\
\text { Perorangan }\end{array}$ & 0,01 & 1,21 & 1,00 & $-0,03$ & $-0,42$ & 1,28 & 0,8 & 0,56 \\
\hline
\end{tabular}

Dari data BPS yang diolah, diperoleh angka yang menunjukkan pertumbuhan daya serap sektor lapangan pekerjaan di Indonesia tahun 2011 - 2017. Perdagangan, rumah makan, dan jasa akomodasi menjadi sektor dengan pertumbuhan daya serap tertinggi tujuh tahun belakangan ini, dimana rata-rata pertumbuhannya adalah 0,70 persen. Kemudian, sektor selanjutnya yang banayak berkontribusi dalam penyerapan tenaga kerja adalah jasa kemasyarakatan, sosial, dan perorangan, dengan daya serap rata-rata sebesar 0,56 persen. Sedangkan sektor lapangan pekerjaan dengan daya serap terendah adalah pertanian, perkebunan, perburuan, dan perikanan, dimana rata-rata pada tiap tahunnya sektor daya serap tenaga kerja pada sektor ini menurun sebesar 0,7 persen.

Studi Elshamy (2013) berkenaan dengan hasil uji pada penelitian ini, dalam penelitiannya pada negara Mesir Ia menemukan turunnya angka pengangguran sebesar 0,02 persen tiap kenaikan PDRB sebesar 1 persen, begitu pula dengan penelitian Salman dan Shukur (2014) yang membuktikan turunnya angka pengangguran sebesar 0,04 persen setiap kenaikan 1 persen PDRB. Adanya hubungan terbalik antar dua variabel ini juga didukung oleh penelitian Chand, dkk (2017), ia menemukan bahwa kenaikan PDRB sebesar 1 persen akan menekan angka pengangguran sebesar 0,7 persen. Hasil uji ini bersangkutan dengan Teori Keynes yang mengakatakan bahwa pengangguran merupakan akibat dari rendahnya permintaan agregat, sehingga ketika permintaan agregat rendah maka angka produksipun akan rendah, kondisi tersebut kemudian akan menekan permintaan di pasar tenaga kerja.

Selanjutnya, pada pengujian terhadap variabel inflasi diperoleh koefisien sebesar -0.008315 . Koefisien tersebut menunjukkan kenaikan inflasi sebesar 1 persen akan menekan angka pengangguran sebesar 0,008 persen. Hasil uji membuktikan adanya hubungan negatif antara variabel inflasi dan pengangguran, sehingga hipotesa penelitian $\left(\mathrm{Ha}_{2}\right)$ diterima.

Hasil pengujian memiliki korelasi dengan teori Kurva Phillips yang meyakini pengangguran akan turun apabila inflasi naik. Pada Kurva Phillips jangka panjang, terjadinya pengangguran pada jumlah tertentu akan mendorong pemerintah untuk melakukan kebijakan fiskal dan moneter ekspansif untuk menekan angka pengangguran, dampak dari kebijakan tersebut akan meningkatkan permintaan agregat meskipun mendorong naiknya angka inflasi. Untuk memperoleh laba yang lebih besar, perusahaan akan menambah jumlah produksinya, untuk mecapai hal tersebut perusahaan membutuhkan tenaga kerja yang memadai sehingga perusahaan menambah penyerapan kerja melalui rekruitmen (Feriyanto, 2014)

Melihat kondisi inflasi Indonesia pada tahun 2011 hinga 2017 pengaruh negatif inflasi terhadap pengangguran merupakan fenomena yang logis, hal ini dikarenakan pada rentang tahun tersebut fluktuasi angka inflasi sejalan dengan fluktuasi angka investasi. Untuk membuktikan argumen tesebut berikut disajikan grafik kombinasi pergerakan inflasi dan investasi

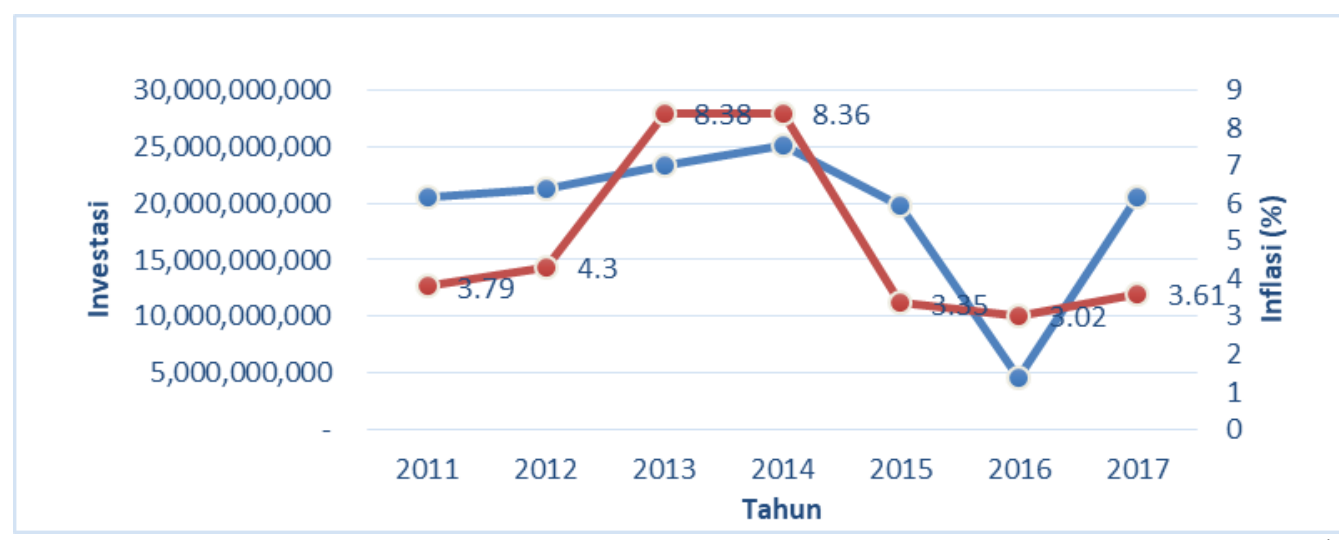

Sumber : World Bank, Foreign direct investment, net inflows (BoP, current US\$) (Diolah)

Gambar 5. Grafik Investasi dan Inflasi Indonesia

Grafik di atas mengkomparasikan pertumbuhan investasi dan inflasi di Indonesia tahun 2011 sampai tahun 2017. Dapat dilihat bahwa dalam tujuh tahun terakhir pertumbuhan inflasi sejalan dengan pertumbuhan investasi. Artinya, inflasi yang tinggi mendorong investasi yang tinggi pula, begitu juga sebaliknya. Sebagai contoh, tahun 2012 inflasi Indonesia adalah 4,3 persen dengan investasi sebesar US\$ 21.200.778.607,87 . Kemudian, di tahun 2013 inflasi melonjak menjadi 8,38 persen, hal ini diiringi dengan naiknya investasi menjadi 23.281.742.361,53 . 
Adanya pertumbuhan inflasi yang sejalan dengan investasi kemudian akan berdampak pada penyerapan tenaga kerja. Sehingga semakin tinggi tingkat inflasi yang kemudian dibarengi pertumbuhan investasi akan berdampak pada naiknya permintaan di pasar tenaga kerja.

Sejalan dengan hasil penelitian, teori, dan argumen, Kasseh (2018) pada penelitiannya terhadap Negara Gambia menemukan adanya pengaruh negatif signifikan inflasi terhadap pengangguran, begitu pula dengan studi Vermeulen (2017), ia menemukan pada estimasi jangka panjang, inflasi dan pengangguran merupakan sebuah trade-off. Ketika inflasi tinggi maka produsen akan meningkatkan kuantitas produksinya, dimana hal tersebut membutuhkan tambahan input salah satunya tenaga kerja.

Kemudian, hasil uji terhadap pengaruh upah minimum terhadap pengangguran menunjukkan hasil yang berbeda dengan hipotesa yang terbentuk di awal penelitian ( $\left.\mathrm{Ha}_{3}\right)$. Koefisien yang didapatkan ialah sebesar -0.225280, dimana hasil ini menyatakan bahwa kenaikan upah minimum sebesar satu persen akan menekan angka pengangguran sebesar 0,23 persen. Hal ini tentunya bertentangan dengan teori kurva upah minimum di pasar kompetitif, begitu pula dengan penelitian sebelumnya yang mengatakan bahwa upah minimum berpengaruh positif terhadap pengangguran. Secara teori, apabila karakteristik dari pasar tenaga kerja suatu wilayah adalah kompetitif maka upah minimum akan berpengaruh negatif terhadap tingkat pengangguran daerah tersebut. Namun, lain halnya apabila karateristik pasar tenaga kerja merupakan monopsoni, hal tersebut akan dijelaskan melalui kurva berikut

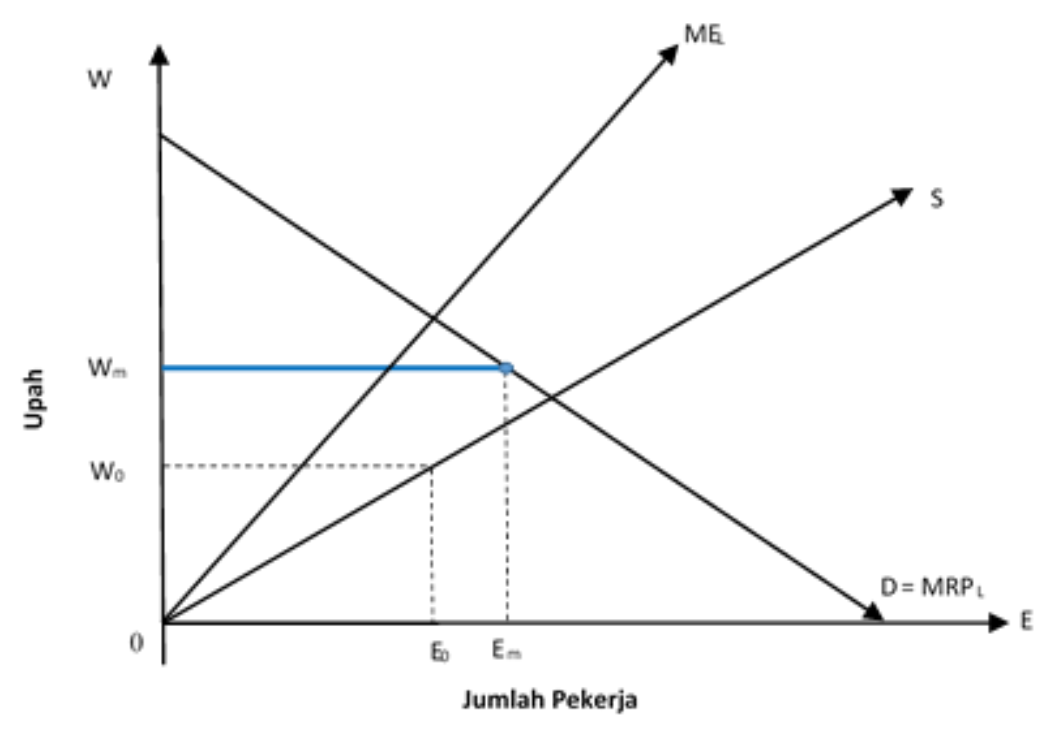

(Ehrenberg and Smith, 2012)

Gambar 6. Upah Minimum pada pasar Monopsini

Untuk memaksimalkan laba, perusahaan merekrut tenaga kerja hingga di di titik $\mathrm{ME}_{\mathrm{L}}$ memotong $M R P_{L}$, pada titik tersebut perusahaan akan memberikan upah sebesar $\mathrm{W}_{0}$ kepada karyawannya dengan jumlah tenaga kerja sebesar $\mathrm{E}_{0}$. Ketika pemerintah menetapkan kebijakan upah minimum yang lebih tinggi dibandingkan upah awal $\left(\mathrm{W}_{\mathrm{m}}\right)$ yang diberikan oleh perusahaan, maka akan menciptakan kurva hotizontal baru, kurva ini kemudian memotong $\mathrm{MRP}_{\mathrm{L}}$, sehingga apabila perusahaan hendak memaksimalkan laba dengan menyesuaikan biaya marginal dan pendapatan marginalnya, maka jumlah pekerja yang harus direkrut sebesar $E_{m}$. Kondisi ini menunjukkan bahwa meskipun upah naik dari $W_{0}$ ke $\mathrm{W}_{\mathrm{m}}$, jumlah tenaga kerja akan ikut naik dari $\mathrm{E}_{0} \mathrm{ke} \mathrm{E}_{\mathrm{m}}$ (Ehrenberg and Smith, 2012).

Pada pasar monopsoni, upah minimum akan mendorong naiknya average cost dan menekan pengeluaran marginal, kemudian biaya marginal juga semakin rendah sehingga mendorong perusahaan untuk menambah output.

Pada pasar monopsoni perusahaan akan membayarkan upah yang lebih tinggi salah satunya untuk meningkatkan kualitas jasa yang dihasilkan karyawannya, selain itu upah yang lebih tinggi akan menjadi daya tarik calon tenaga kerja (Pratomo, dkk 2011). Sejalan dengan teori ini, Feriyanto (2014) mengindikasikan upah pekerja yang lebih tinggi menunjukkan terbukanya kesempatan kerja yang baik. Selain itu, studi kasus pada fenomena perusahaan Henry Ford menunjukkan bahwa upah yang tinggi akan memotivasi pekerja sehingga menghasilkan output yang lebih efisien, kondisi ini akan menekan biaya produksi meskipun perusahaan harus meningkatkan upah yang diberikan. 
Kemudian, dari regresi variabel jumlah penduduk terhadap variabel pengangguran diperoleh koefisien sebesar 0.477383 dengan probabilitas sebesar 0.6251 . Hasil ini menolak hipotesa di awal penelitian $\left(\mathrm{Ha}_{4}\right)$, dimana output pengujian menunjukkan jumlah penduduk tidak berpengaruh signifikan terhadap pengangguran.

Hasil uji bertolak belakang dengan studi terdahulu oleh Gideon (2017) yang menemukan adanya pengearuh positif jumlah penduduk terhadap pengangguran, hal ini ditunjukkan dengan naiknya jumlah penduduk Nigeria di beberapa tahun belakangan menyebabkan tingkat pengangguran naik sebesar 25,1 persen di tahun 2014.

\section{Simpulan dan saran}

Dari hasil uji dan analisis data, dapat disimpulkan sebagai berikut : Produk Domestik Regional Bruto (PDRB) berpengaruh negatif signifikan terhadap pengangguran di Indonesia tahun 2011 - 2017 , dimana tiap terjadi kenaikan PDRB sebesar 1 persen akan menekan angka TPT sebanyak 0.72 persen. Adapun sektor yang 7 tahun terakhir ini berperan besar dalam penyerapan tenaga tenaga kerja adalah Perdagangan, Rumah Makan dan Jasa Akomodasi, dimana rata-rata pertumbuhan lapangan pekerjaannya 0,70 persen.

Selanjutnya, penelitian ini membuktikan inflasi berpengaruh negatif dan signifikan terhadap pengangguran di Indonesia tahun 2011 - 201, hasil angka TPT turun sebesar -0.008315 setiap kenaikan angka inflasi sebanyak 1 persen. Angka pengangguran yang turun akibat naiknya inflasi salah satunya disebabkan oleh naiknya angka inflasi yang dibarengi oleh naiknya angka investasi, sehingga naiknya harga di pasar menciptakan iklim investasi yang baik. Hal ini kemudian mendorong naiknya produktifitas dan penyerapan tenaga kerja.

Kemudian, variabel upah minimum berpengaruh negatif signifikan terhadap pengangguran di Indonesia 2011 - 2017, dimana setiap terjadi kenaikan upah minimum sebesar satu persen akan menekan TPT sebanya 0.225280 . Hal ini bersinggungan dengan kurva minimum di pasar monomsoni, dimana ketika upah minimum dinaikkan, maka jumlah pengangguran akan berkurang.

Pada variabel jumlah penduduk hasil uji membuktikan tidak adanya berpengaruh variabel terebut terhadap pengangguran, hal ini ditunjukkan dari probabilitas variabel jumlah penduduk pada uji regresi data panel yang nilainya lebih dari taraf nyata $(\alpha=10 \%)$.

Berdasarkan kondisi yang telah diuraikan di atas, maka kebijakan yang dapat di ambil oleh pemerintah untuk menekan angka pengangguran adalah menjaga upah minimum dari tahun ke tahun karena selain memotivasi dan membantu masyarakat untuk mendapatkan upah yang layak, tingkat upah minimum diyakini dapat menekan angka pengangguran secara signifikan. Kemudian diperlukan studi lebih lanjut mengenai kebijakan yang tepat untuk menaikkan PDRB, karena studi ini membuktikan naiknya angka PDRB akan menekan pengangguran.

\section{Daftar Rujukan}

Byrne, D. and Strobl, E. (2004) Defining unemployment in developing countries: Evidence from Trinidad and Tobago, Journal of Development Economics, 73(1), pp. 465-476. doi: 10.1016/j.jdeveco.2002.12.005.

Caliendo, M. et al. (2018) The short-run employment effects of the German minimum wage reform, Labour Economics, 53, pp. 46-62. doi: 10.1016/j.labeco.2018.07.002.

Chand, K., Tiwari, R. and Phuyal, M. (2017) Economic Growth and Unemployment Rate : An Empirical Study of Indian Economy, 4(2), pp. 130-137. doi: 10.17492/pragati.v4i02.11468.

Elshamy, H. (2013) The Relationship Between Unemployment and Output in Egypt, Procedia - Social and Behavioral Sciences. Elsevier B.V., 81, pp. 22-26. doi: 10.1016/j.sbspro.2013.06.381.

Gideon, H. E. (2017) Impact of Population Growth on Unemployment in Nigeria, American University of Nigeria Departement of Economics.

Gujarati, Damodar N. 2006. Ekonometrika Dasar. Jakarta : Penerbit Erlangga.

https://data.worldbank.org/indicator/BN.KLT.DINV.CD (Diakses 28 Juli 2019, 15.11). 
https://data.worldbank.org/indicator/SL.UEM.1524.ZS?locations=EG\&year_high_desc=false (Diakses 3 Juli 2019, 13.34).

https://kemenperin.go.id/kompetensi/UU_13_2003.pdf (Diakses 4 Juli 2019, 00.12).

https://money.kompas.com/read/2015/11/05/171744726/BPS.Tingkat.Pengangguran.Terbuka.Mening kat.dari.Tahun.Sebelumnya (Diakses 3 Juli 2019, 15.20).

https://www.bps.go.id/statictable/2009/04/16/970/penduduk-15-tahun-ke-atas-yang-bekerjamenurut-lapangan-pekerjaan-utama-1986---2018.html (DIakses 27 Juli 2918, 14.20).

https://www.bps.go.id/statictable/2016/04/04/1907/penduduk-berumur-15-tahun-ke-atas-menurutprovinsi-dan-jenis-kegiatan-selama-seminggu-yang-lalu-2008---2018.html (Diakses 4 Juli 2019, 19.27).

Kasseh, P. A. (2018) The Relation between Inflation and Unemployment in the Gambia: Analysis of the Philips Curve, Journal of Global Economics, 06(02), pp. 6-12. doi: 10.4172/2375-4389.1000294.

Mankiw, N. G. (2018) Principles of Economics, 8th ed. Boston: Cengage Learning.

Salman, A. K. and Shukur, G. (2014) Investigating Causal Relations between the GDP Cycle and Unemployment: Data from Finland, 6(4), pp. 118-134. doi: 10.5539/ijef.v6n4p118.

Mulyadi,S.2003. Ekonomi Sumber Daya Manusia dalam Perpektif Pembangunan. Jakarta: PT Raja Grafindo Persada.

Uk Kim, C. and Lim, G. (2018) Minimum Wage and Unemployment: An Empirical Study on OECD Countries. Journal of Reviews on Global Economics, 7, pp. 1-9. doi: 10.6000/1929-7092.2018.07.01.

Vermeulen, J. C. (2017) Inflation and unemployment in South Africa : Is the Phillips curve still dead?, pp. 20-54.

Winarno, Wahyu W. (2007). Analisis Ekonometrika dan Statistika dengan Eviews (Edisi 2). Yogyakarta : UPP STIM YKPN.

Winarno, Wahyu W. (2015). Analisis Ekonometrika dan Statistika dengan Eviews (Edisi 4). Yogyakarta : UPP STIM YKPN 